International Journal of Life Sciences
Available online at http://sciencescholar.us/journal/index.php/ijls
Vol. 2 No. 1, April 2018, pages: $42 \sim 49$
e-ISSN: 2550-6986, p-ISSN: 2550-6994
http://dx.doi.org/10.29332/ijls.v2n1.93

\title{
Responses of Corncob as Replacement of Elephant Grass on Performance and Carcass Profile of Bali Cattle
}

\author{
Q Crossmark \\ NLP Sriyani a, Wayan Siti ${ }^{\text {b }}$, Gede Suarta c, Ida Bagus Gaga Partama d, Nyoman Tirta Ariana e,
Wayan Sayang Yupardhi ${ }^{\text {e }}$
}

Article history: Received 8 June 2017, Accepted in revised form 25 January 2018, Approved 25 February 2018, Available online 3 March 2018

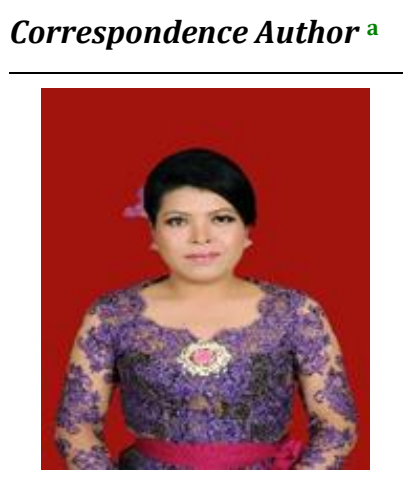

Keywords

Bali Cattle;

Carcass profile;

Corncob;

Elephant Grass;

Fermented corncob;

\begin{abstract}
The purpose of this study was to determine the effect of corncob instead of elephant grass in the diet of cattle on the performance and carcass profile of the Bali Cattle. Total of $15 \%$ and $30 \%$ of elephant grass in the diet was replaced with a fermented corncob. This study used a Randomized Complete Design, which consists of 3 treatments, each treatment consisted of 4 replicates. The study used 12 male Bali Cattle with an initial average body weight of $226 \mathrm{~kg}$. The cattle were allocated randomly into 3 treatments where cattle received the control treatment R0 (ration with $60 \%$ of elephant grass $+10 \%$ gliricidia + $10 \%$ calliandra $+20 \%$ pollard), R1 (ration with $45 \%$ of elephant grass $+15 \%$ corncob $+10 \%$ gliricidia $+10 \%$ calliandra $+20 \%$ pollard) and R2 (ration with $30 \%$ of elephant grass $+30 \%$ corncob $+10 \%$ gliricidia $+10 \%$ calliandra $+20 \%$ pollard). The results of this study showed that daily weight gain of R0 was 0.61 $\mathrm{kg}$, R1 was $0.61 \mathrm{~kg}$ and R2 was $0.62 \mathrm{~kg}$. They were not significantly different (P> $0.05)$, among the treatments the R0 carcass percentage was $50.29 \%$, R1 was $51.57 \%$ and R2 was $51.70 \%$. They were not significantly different $(\mathrm{P}>0.05)$ among the treatments. Fleshing index (FI) each other value of R0 was 1.36, R1 was 1.33 and $R 2$ was 1.29 were not significantly different $(P>0.05)$ each other. Size of loin eye of R0 $=64.4 \mathrm{~cm} 2 \mathrm{R} 1=64 \mathrm{~cm} 2$ and R2 $=64.01 \mathrm{~cm} 2$ were not significantly different $(\mathrm{P}>0.05)$ each other. The conclusion of the study was the substitution of elephant grass as a basal diet with fermented corncob for $15 \%$ and $30 \%$ on the Bali Cattle feedlot were no significant effect on performance and carcass profiles. Substitution of elephant grass with corncob can be done up to $30 \%$ on the Bali Cattle feed.
\end{abstract}

a Faculty of Animal Science Udayana University, PB Sudirman Street Denpasar, Bali, Indonesia

b Faculty of Animal Science Udayana University, PB Sudirman Street Denpasar, Bali, Indonesia

c Faculty of Animal Science Udayana University, PB Sudirman Street Denpasar, Bali, Indonesia

d Faculty of Animal Science Udayana University, PB Sudirman Street Denpasar, Bali, Indonesia

e Faculty of Animal Science Udayana University, PB Sudirman Street Denpasar, Bali, Indonesia

f Faculty of Animal Science Udayana University, PB Sudirman Street Denpasar, Bali, Indonesia 
e-ISSN: 2550-6986, p-ISSN: 2550-6994@C Copyright 2018. The Author.

SS Journals Published by Universidad Técnica de Manabí.

This is an open-access article under the CC BY-SA 4.0 license

(https://creativecommons.org/licenses/by-sa/4.0/)

All rights reserved.

\section{Contents}

Abstract

1. Introduction

2. Research Method

3. Results and Analysis

4. Conclusion

Acknowledgements

\section{Introduction}

An action to develop the Bali Cattle to be beef cattle toward the government program for the fulfillment of national food must be accompanied with some efforts to increase the availability of feed. In general, the problem that is still experienced by almost of breeders is the low livestock productivity caused by the low quantity and quality of feed so that cattle are not able to meet the standard of living necessities and production. The availability of feed ingredients in the tropics country of Indonesia particularly on the Bali island is very fluctuated and its dependent on season. The condition of the rainy season causes forage available much, but in the dry season, it becomes limited. This has a systemic effect on the low increase of ruminant livestock production. Therefore it is necessary to pay more attention to the strategy of the fulfillment of quantity and quality of feed all over the year.

Strategies that can be implemented in the community is to utilize agricultural wastes products such as crop residues (rice straw, corn straw, corncob, cassava, coffee skin, cocoa skin, etc.) for cattle feed. The potential of crop residues should be formulated in such a way as to be a continuous source of feed ingredients. One of the feed ingredients derived from the agricultural waste product is corncob. It is strategic enough to be used as alternative feed for beef cattle, given abundant potency and it is still not used optimally at farmer level.

In general at, the level of the breeder, grasses one then and source of fiber, both native grass and superior grass such as elephant grass and others. The name of grass availability in the farmer's community is limited, especially in critical areas and in the dry season. Referring to the above problems they need to find out another alternative source of fiber feed such as corn cob. Utilization of corncob for feed as a source of fibrous energy derived from carbohydrate structure. This research was conducted to know the production response of the Bali Cattle with using corn cob as a substitution of elephant grass.

\section{Research Method}

Location and Time of Research

The research in the form of cattle raising was carried out in the shelter at Pempetan Village, Rendang District, Karangasem Regency, Bali Province. Cattle maintenance was carried out for 3 months. Then the animal was a slaughter at Mambal Slaughter House at Mambal Village of Badung Regency.

\section{Animal and Feed}

. There were 12 male calves aged 2-2.5 years old with an average initial body weight of $226.67 \mathrm{~kg}$ were divided into 3 feed treatments. Their feed composition is presented in Table 1.

Sriyani, N., Siti, W., Suarta, G., Partama, I., Ariana, N., \& Yupardhi, W. (2018). Responses of Corncob as Replacement of Elephant Grass on Performance and Carcass Profile of Bali Cattle. International Journal Of Life 
Table 1

The feed composition and crude protein content (CP) and total digestible nutrients (TDN) expressed in dry matter percentage.

\begin{tabular}{lrrr}
\hline \multicolumn{1}{c}{ Inggredient (\%) } & \multicolumn{3}{c}{ Ration } \\
\cline { 2 - 4 } & \multicolumn{1}{c}{ R0 } & R1 \\
\hline Elephant Grass & 60,00 & 45,00 & 30,00 \\
Corncob & - & 15,00 & 30,00 \\
Gliricidia & 10,00 & 10,00 & 10,00 \\
Calliandra & 10,00 & 10,00 & 10,00 \\
Polard & 20,00 & 20,00 & 20,00 \\
Total & 100,00 & 100,00 & 100,00 \\
\hline Nutrient : & & & \\
DM (\%) & 49,21 & 57,17 & 59,14 \\
CP (\%) & 16,71 & 14,69 & 13,49 \\
Crude fiber (\%) & 15,48 & 16,51 & 17,29 \\
Total digestible nutrients (\%) & 72,14 & 68,58 & 65,9 \\
\hline
\end{tabular}

\section{Fermentation of Corncob}

Before corncob was given to the cattle, it was fermented formerly. Combination corncob with polar was in a ratio of $100 \mathrm{~kg}$ corncob and $5 \mathrm{~kg}$ pollard. Stater or Micro-Organisms Local (MOL) was dissolved in water then the mixed corncob and Pollard was flushed bit by bit gradually with MOL solution then stirred until homogenous. Put the mixture into a plastic bag then tied for about 7 days. After the fermentation was completed corncob is removed from plastic bag for airy it before given to the animal.

\section{Research Design}

The research used Completely Randomized Design, which consisted of 3 rations treatment and 4 replications in each treatment so that the number of the animal used was 12 .

The 3 treatments of rations were as follows:

Treatment R0 (control) : $60 \%$ elephant grass $+10 \%$ gliricidia $+10 \%$ calliandra $+20 \%$ polard

Treatment R1 : $45 \%$ elephant grass $+15 \%$ corncob $+10 \%$ gliricidia $+10 \%$ calliandra $+20 \%$ polard

Treatment R3 $\quad: 30 \%$ elephant grass $+30 \%$ corncob $+10 \%$ gliricidia $+10 \%$ calliandra $+20 \%$ polard

\section{Cattle Weighed}

The first weighed was conducted at the beginning of the research before the cattle were sheltered and grouped according to the treatment group. Subsequently weighed once every month during the research to determine the average daily weight gain and for subsequent feeding adjustments.

\section{Cattle Slaughter and Meat Sample}

After being reared for 3 months with different ration treatment according to the group, then $25 \%$ of the animal in each treatment were taken to slaughter. Before they were slaughtered they weighed to get the slaughter weight. Slaughter was done on the neck by cutting the skin, muscles, jugular vein, trachea, esophagus and carotid artery. The animals were slaughtered at Mambal Slaughter House, Badung Regency.

\section{Data Analysis}

Data were taken included weight gain, feed consumption, feed conversion ratio (FCR) and carcass percentage. The data obtained were analyzed with variance using completely randomized design, and the significant difference between treatments was tested with Duncan's multiple range test (Steel and Torrie, 1991). 
3. Results and Analysis

\subsection{Performance of the Animal}

Consumption of dry matter ingredients of 3 treatments i.e R0 (control) $=6.36 \mathrm{~kg}, \mathrm{R} 1=6.18 \mathrm{~kg}$ and R2 $=$ $6.41 \mathrm{~kg}$. The results showed that there were no significant differences among those treatments on dry ingestion (Table 2). This showed that replacement of elephant grasses for $15 \%$ and $30 \%$ had no effect on the animal appetite. According to Kearl (1982), the requirement of dry ingredient per head per day is between 2.8 to $3 \%$ of body weight. The amount of consumption in the percentage of body weight will have a close relationship with capacity and digestive tract, especially rumen. Pond et al. (1995) stated that the limited consumption of feed is usually affected by the normal state of the gastrointestinal tract and some of the tissues in the organs associated with it.

Table 2

The Effect of Using Corncob as Basal Feed on Fattening Cattle

\begin{tabular}{llll}
\hline \multirow{2}{*}{ Variable } & \multicolumn{3}{c}{ Treatment } \\
\cline { 2 - 4 } & R0 & R1 & R2 \\
\hline Consumtion DM (kg/h) & $6,36^{\mathrm{a}}$ & $6,18^{\mathrm{a}}$ & $6,41^{\mathrm{a}}$ \\
average daily weight gain ADG $(\mathrm{kg} / \mathrm{h})$ & $0,61^{\mathrm{a}}$ & $0,61^{\mathrm{a}}$ & $0,62^{\mathrm{a}}$
\end{tabular}

Feed Conversion Ratio

$10,43^{\text {a }} \quad 10,13^{\text {a }} \quad 10,13^{\text {a }}$

Explanation :

Treatment R0 (control): $60 \%$ elephant grass $+10 \%$ gliricidia $+10 \%$ calliandra $+20 \%$ polard

Treatment R1: $45 \%$ elephant grass $+15 \%$ corncob $+10 \%$ gliricidia $+10 \%$ calliandra $+20 \%$ polard

Treatment R3: $30 \%$ elephant grass $+30 \%$ corncob $+10 \%$ gliricidia $+10 \%$ calliandra $+20 \%$ polard

a Means inthe same row by the same letter are not significant differen $(P>0,05)$

The average daily weight gain (ADG) is one of the factors expected in the cattle fattening business. It is often used as a benchmark because it is closely related to income (Utomo, 2001). Weight gain can be determined by weighing the livestock repeatedly any time so that it can be presented daily or weekly weight gain increments (Tillman et al., 1998). The results of the research indicated that replacement of the grass with corncob $15 \%$ and $30 \%$ were no significant effect on animal production that indicated by a variable of daily weight gain. This was due to the grass that as a basal feed was replaced with corncob for $15 \%$ and $30 \%$ produces feed consumption in the form of dry matter ingredient was not significantly different in all treatments. Daily weight gain is a manifestation of the quality of feed given. The results of the research showed that weight gain was higher than the cattle reared with a farming system that reach weight gain for $0.3 \mathrm{~kg} /$ day that fed grass only.

Based on the average weight gain per head per day and the average feed consumed per head per day, it can be calculated that the feed conversion ratio (FCR) was a reflection of the amount of feed needed by livestock to reach $1.0 \mathrm{~kg}$ meat where it that is the comparison between feed consumed and weight gain was produced. High feed conversion ratio is an indication of the inefficiency use of feed by animals, whereas low feed conversion ratio indicates the efficient use of feed. The result of statistical analysis of feed conversion rate in the research was not significantly different. Feed consumption is declared efficient when producing weight gain with the lowest conversion value of feed (Anonimus, 1998).

\subsection{Bali Cattle Carcass Profile}

Carcass percentage of treatment $\mathrm{R} 0$ (control) $=50.29 \% \mathrm{R} 1=51.57 \%$ and $\mathrm{R} 2=51.70 \%$. Those mean that the substitution of grass with $15 \%$ and $30 \%$ of corncob could increase the percentage of the carcass. It was presumed that fermented corncob provides better feed digestibility in the rumen. However, this requires further study, especially on the variable of feed degradation from corncob both in vitro and in

Sriyani, N., Siti, W., Suarta, G., Partama, I., Ariana, N., \& Yupardhi, W. (2018). Responses of Corncob as Replacement of Elephant Grass on Performance and Carcass Profile of Bali Cattle. International Journal Of Life Sciences (IJLS), 2(1), 42-49. doi:10.29332/ijls.v2n1.93 
vivo. The feed ingested by a livestock would be converted into glycogen form substances stored in the liver and muscles.

Table 3

Effect of Corncob Used as Basal Feed on Cattle Fattening to Characteristic of Bali Cattle Carcasses

\begin{tabular}{llll}
\hline \multicolumn{1}{c}{ Variable } & \multicolumn{2}{c}{ Treatment } & $\mathrm{R} 2$ \\
\cline { 2 - 4 } & $\mathrm{R} 0$ & $\mathrm{R} 1$ & $325^{\mathrm{a}}$ \\
Slaughter weight $(\mathrm{kg})$ & $338^{\mathrm{a}}$ & $318^{\mathrm{a}}$ & $168^{\mathrm{a}}$ \\
Carcass weight $(\mathrm{kg})$ & $170^{\mathrm{a}}$ & $164^{\mathrm{a}}$ & $51,70^{\mathrm{a}}$ \\
Carcass weight $(\%)$ & $50,29^{\mathrm{a}}$ & $51,57^{\mathrm{a}}$ & $126^{\mathrm{a}}$ \\
Carcass length (cm) & $125^{\mathrm{a}}$ & $127^{\mathrm{a}}$ & $1,33^{\mathrm{a}}$ \\
Fleshing Index, (FI) kg/cm & $1,36^{\mathrm{a}}$ & $1,29^{\mathrm{a}}$ & $64,01^{\mathrm{a}}$ \\
Eye muscle area (cm $\left.{ }^{2}\right)$ & $64,0^{\mathrm{a}}$ & $64,4^{\mathrm{a}}$ & $2,5^{\mathrm{a}}$ \\
Thick of back fat (mm) & $2,6^{\mathrm{a}}$ & $2,5^{\mathrm{a}}$ & \\
\end{tabular}

\section{Explanation :}

Treatment R0 (control): $60 \%$ elephant grass $+10 \%$ gliricidia $+10 \%$ calliandra $+20 \%$ polard Treatment R1: $45 \%$ elephant grass $+15 \%$ corncob $+10 \%$ gliricidia $+10 \%$ calliandra $+20 \%$ polard Treatment R3: 30\% elephant grass $+30 \%$ corncob $+10 \%$ gliricidia $+10 \%$ calliandra $+20 \%$ polard a Means inthe same row by the same letter are not significant differen $(\mathrm{P}>0,05)$

Glycogen is a major form of carbohydrate deposits in cattle. The percentage of carcasses in the research was lower than the results obtained in the study using $60 \%$ of elephant grass plus $40 \%$ concentrate which obtained the percentage of carcasses for 53.54\% (Sriyani, 2013). At the slaughter weight for about $400 \mathrm{~kg}$ the Bali cattle could reach carcass weight about $55-58 \%$.

Value of Flashing Index Carcase within 3 treatments i.e control R0 = 1.36, R1 = 1.29 and R2 = 1.33, were still very low (Table 3). This means that the carcass rate of the Bali cattle was still very low. Heavy muscling that is achieved by European breed cattle (Bos taurus) having undergone intensive selection towards high meat production can achieve Fleshing Index about 1,81-2.05 kg per cm of carcass length (round carcass shape) up to more than $2.05 \mathrm{~kg}$ per $\mathrm{cm}$ of carcass length (round carcass shape). Fleshing index Carcasses with low have a thin-looking shape, resembling a skeleton because carcasses are mild in areas with potentially heavy muscle (such as round, loin, prime rib, and chuck) and tend to be long and thin in the neck, front and back legs and have a deep chest. The length of the carcass is more affected by the growth of the vertebra segment which lies between the first border of the first rib and the rear os coxae. This tissue grows and develops prematurely so that its linear size is more difficult to be affected by a feed or other treatment during growth.

The area of eye muscle in this research of treated R0 (control) $=64.03 \mathrm{~cm} 2$ treatment R1 $=64.4 \mathrm{~cm} 2$ and R2 $=64.01 \mathrm{~cm} 2$ (Table 5.2). Bali cattle that were cut in the Slaughter-House of Animal at Pesanggaran have eye muscle area for $62.2 \mathrm{~cm} 2$. The magnitude of the proportion of muscle in carcass can be predicted from the area of eye muscle the larger the eye muscle area the bigger proportion of carcasses (Romans, et al., 1994). The area of eye muscle in this research was not much different than that of eye muscle area in the research fed $60 \%$ elephant grass and 40\% concentrate that reach $60.03 \mathrm{~cm} 2$ (Sriyani, 2013).

Back fat thickness is an indicator to determine the deposition of body fat or carcass. The thicker the back fat means the greater the proportion of carcass fat. Soeparno (2011), stated that by increasing age and energy consumption, fat loss will occur between the muscles (intramuscular fat), the lower fat layers of the skin (subcutaneous fat) and lastly between muscle fibers (intramuscular fat) or marbling. Priyanto et al., (1999) stated that fatty meat has a preferred palatability, especially tenderness and juiciness due to increased of marbling in the meat. The thickness of the back fat serves to prevent the evaporation of carcass during aging. The thinner the total backfat thickness greater it evaporation potential, where measurement of it the measurable in this research can be classified as very thin, i.e. generally average is $3.2 \mathrm{~mm}$. This phenomenon is common in tropical cattle as a climate and environmental influences. This 
situation is actually less favorable in terms of quality of meat if carcasses with thin subcutaneous fat are aging at temperatures lower than $5^{\circ} \mathrm{C}$.

These grease fats act as insulators against cold temperatures so that the rate of carcass temperature decrease does not go too fast by the influence of low temperatures inside the aging room $\left(4^{\circ} \mathrm{C}\right)$. Carcasses are thin fat, will result in the phenomenon of cold constructing or shortening of muscle fibers so that the meat will become tougher. The optimal thickness of carcass is 7.6-10.2 mm (Kempster et al., 1982).

\section{Conclusion}

The conclusion of this research is elephant grass could be substituted with a corncob up to $30 \%$ as an animal feed of the Bali Cattle.

\section{Acknowledgments}

The authors thank the head and staff of the Mambal Slaughter House and the Laboratory of Animal Products and Microbiology, Faculty of Animal Science Udayana University for their cooperation during the research period.

Sriyani, N., Siti, W., Suarta, G., Partama, I., Ariana, N., \& Yupardhi, W. (2018). Responses of Corncob as Replacement of Elephant Grass on Performance and Carcass Profile of Bali Cattle. International Journal Of Life 


\section{References}

1. Kempster, A. J., Cuthbertson, A., \& Harrington, G. (1982). Carcase evaluation in livestock breeding, production and marketing. Granada Publishing Limited.

View in (Google Scholar)

2. Priyanto, R., Johnson, E. R., \& Taylor, D. G. (1999). The economic importance of genotype in steers fed pasture or lucerne hay and prepared for the Australian and Japanese beef markets. New Zealand Journal of Agricultural Research, 42(4), 393-404.

View in (Google Scholar)

3. Romans, J. R., Costello, W. J., Carlson, C. W., Greaser, M. L., \& Jones, K. W. (1994). The meat we eat.,(Interstate Publishers, Inc.: Danville, IL).

View in (Google Scholar)

4. Konsentrat, D., \& Bali, P. P. K. Peternakan Tropika Peternakan Tropika. View in (Google Scholar)

5. Steel, R. G. D. dan JH Torrie. 1993. Prinsip dan Prosedur Statistika. Suatu Pendekatan Biometrik. Edisi, 2. View in (Google Scholar)

6. Tillman, A. D., Hartadi, H., \& Reksohadiprodjo, S. S. Prawirokusumo dan S. Lebdosoekojo. 1998. Ilmu Makanan Ternak Dasar.

View in (Google Scholar)

7. Utomo, R., \& Djojowidagdo, P. P. D. S. (2001). Penggunaan jerami padi sebagai pakan basal:: Suplementasi sumber energi dan protein terhadap transit partikel pakan, sintesis protein mikroba, kecernaan, dan kinerja sapi potong (Doctoral dissertation, [Yogyakarta]: Universitas Gadjah Mada).

View in (Google Scholar)

8. Suryani, S. A. M. P., \& Arya, I. W. (2017). Improving the Quality of Tilapia (Oreochromis niloticus) With consumption measures Leaf Extract Neem (Azadirachta indica A. Juss) as Antiparasitic. International Journal of Life Sciences (IJLS), 1(3), 28-37.

View in (Google Scholar)

9. Omer, A. M. (2017). Sustainable Development and Environmentally Friendly Energy Systems. International Journal of Physical Sciences and Engineering (IJPSE), 1(1), 1-39.

View in (Google Scholar)

10.Pérez, A. V., Briones, V. V., Viteri, C. G. V., \& Gámez, M. R. (2017). Iberoamerica in Network, GIS \& TIC. International Journal of Social Sciences and Humanities (IJSSH), 1(3), 108-117.

View in (Google Scholar) 


\section{Biography of Author}

\begin{tabular}{|l||}
\hline Ni Luh Putu Sriyani was born in Singaraja, Bali Province in 1973. She graduated \\
her bachelor degree at Udayana University, Faculty of Animal Husbandry in 1996. \\
In 2000, she was appointed a permanent lecturer at Udayana University, Faculty \\
of Animal Husbandry. In 2004, she finished her master degree in Agriculture (MP) \\
at Gadjah Mada University Yogyakarta and in 2013 she completed her doctoral \\
degree in Doctoral Program (S3) at Udayana University of Animal Science. \\
Currently, she is still assigned as a lecturer at Cattle Breeding Laboratory and \\
Udayana University, Faculty of Animal Husbandry. \\
Email address: sriyaninlp@yahoo.co.id
\end{tabular}

Sriyani, N., Siti, W., Suarta, G., Partama, I., Ariana, N., \& Yupardhi, W. (2018). Responses of Corncob as Replacement of Elephant Grass on Performance and Carcass Profile of Bali Cattle. International Journal Of Life Sciences (IJLS), 2(1), 42-49. doi:10.29332/ijls.v2n1.93 